\title{
Educational strategies for the prevention of diabetes, hypertension, and obesity
}

\author{
Alexandre Paulo Machado ${ }^{*}$, Bruno Muniz Lima², Monique Guilharducci laureano², Pedro Henrique Bauth Silva², \\ Giovanna Pereira Tardin², Paulo Silva Reis² ${ }^{2}$, Joyce Sammara Santos ${ }^{2}$, Domingos Jácomo Neto², Eliziana Ferreira D'Artibale ${ }^{2}$ \\ ${ }^{1}$ Adjunct Professor, Department of Health Sciences, Faculdade de Medicina da Universidade Federal de Mato Grosso (UFMT), Cuiabá, MT, Brazil \\ ${ }^{2}$ Medical Student, Faculdade de Medicina da UFMT, Cuiabá, MT, Brazil
}

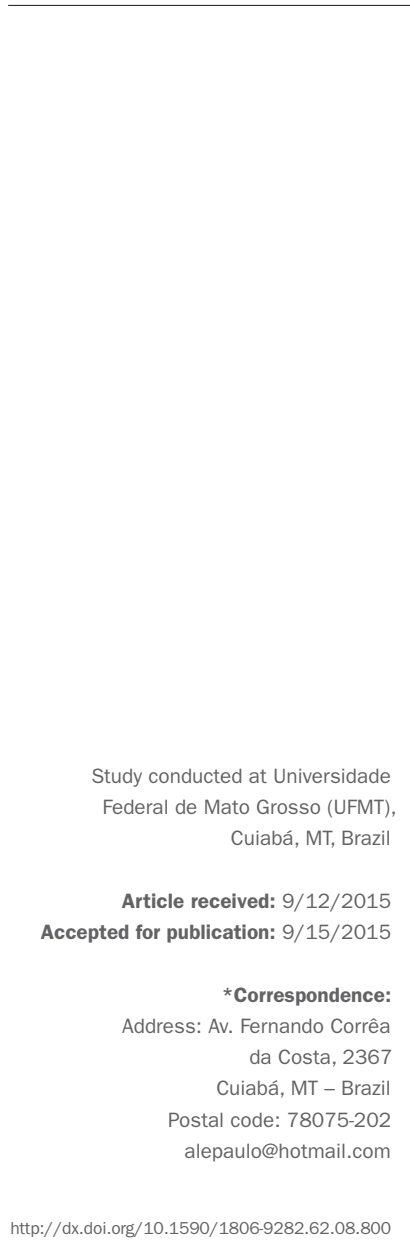

\section{SUMMARY}

Objective: The main goal of this work was to produce a review of educational strategies to prevent diabetes, hypertension, and obesity.

Method: PubMed database was consulted using combined descriptors such as [Prevention], [Educational Activities], [Diabetes], [Hypertension], and [Obesity]. Data from randomized trials published between 2002 and 2014 were included in spreadsheets for analysis in duplicate by the reviewers.

Results: A total of 8,908 articles were found, of which 1,539 were selected about diabetes mellitus (DM, $\mathrm{n}=369)$, arterial systemic hypertension $(\mathrm{ASH}, \mathrm{n}=200)$, and obesity (OBES, $\mathrm{n}=970$ ). The number of free full text articles available was 1,075 $(\mathrm{DM}=276, \mathrm{ASH}=118$ and OBES $=681)$. In most of these studies, demographic characteristics such as gender and age were randomized, and the population mainly composed by students, ethnic groups, family members, pregnant, health or education professionals, patients with chronic diseases (DM, ASH, OBES) or other comorbidities. Group dynamics, physical activity practices, nutritional education, questionnaires, interviews, employment of new technologies, people training and workshops were the main intervention strategies used.

Conclusion: The most efficient interventions occurred at community level, whenever the intervention was permanent or maintained for long periods, and relied on the continuous education of community health workers that had a constant interference inside the population covered. Many studies focused their actions in children and adolescents, especially on students, because they were more influenced by educational activities of prevention, and the knowledge acquired by them would spread more easily to their family and to society.

Keywords: diabetes, hypertension, obesity, prevention, educational intervention.

\section{INTRODUCTION}

The reduction of infant mortality rates, increased life expectancy in many countries (including those in development), and improvements in the diagnosis and treatment of diseases has considerably influenced the growth of the global population, especially adults and the elderly. According to estimates, the number of elderly people in Brazil will reach 32 million by 2020 , with a further forecast that in 2025 the country will occupy sixth place in the world ranking of the ten countries with the largest number of elderly people. ${ }^{1,2}$ The prevalence of chronic diseases increases with age, which reinforces the importance of health prevention interventions targeting healthy habits and better quality of life. ${ }^{3}$
According to the National Survey by Household Sampling (PNAD) - IBGE, in 2003, 29.9\% of the Brazilian population claimed to be suffering from at least one chronic disease, such as: spinal or back disease, arthritis or rheumatism, cancer, diabetes or hyperglycemia, bronchitis or asthma, hypertension, heart disease, chronic kidney disease, depression, tuberculosis, tendonitis or tenosynovitis, and cirrhosis. ${ }^{3}$ Diabetes mellitus (DM), systemic arterial hypertension (SAH), and obesity (OBES) have had a high incidence in the last years.

Previously considered as a problem solely in developed countries, obesity has become a reality that is increasingly present in low and middle-income nations, espe- 
cially in African and Latin American regions. ${ }^{4}$ According to the Ministry of Health, in 2006 the proportion of overweight people in Brazil was $42.7 \%$, advancing in 2011 to $48.5 \%$, with an annual incidence of around $1 \%$. If this pace is maintained, within 13 years, approximately $60 \%$ of the Brazilian population could be overweight. ${ }^{5,6}$

SAH is a multifactorial clinical condition characterized by high and sustained blood pressure levels that are often associated with functional and/or structural changes in target organs (heart, brain, kidneys, and blood vessels) and metabolic disorders. It affects more than $50 \%$ of individuals between 60 and 69 years of age, and $75 \%$ of those over 70 years old. ${ }^{7}$ Regarded as one of the major modifiable risk factors, SAH has become one of the most important public health problems. Educational measures in public health have enabled its reduction and better control of associated complications in nations with high purchasing power. ${ }^{4,7}$

Diabetes mellitus is a heterogeneous group of metabolic disorders that, for the most part, is characterized by hyperglycemia resulting from defects in cell receptors or secretion of insulin, or both. In Brazil, approximately $5.9 \%$ of the population is affected by diabetes. It is estimated that almost $50 \%$ of individuals with diabetes do not know that they have the disease. As seen in SAH, the disease is often asymptomatic and only diagnosed after clinical complications. Diabetes creates a massive economic impact on health services due to the rising costs of treatment, especially when complications occur. ${ }^{8-10}$

In order to decrease the morbidity and mortality related to DM and SAH, during the period 2001-2003 the Ministry of Health implemented the National Arterial Hypertension and Diabetes Mellitus Healthcare Reorganization Plan. This plan included the relationship between the National Federation of Patients with Hypertension and Diabetes Mellitus, State Departments through the CONASS (National Council of Health Departments), Municipal Health Departments through the CONASEMS (National Council of Municipal Health Departments) and the Brazilian Scientific Cardiology, Diabetes, Hypertension, and Nephrology Societies, who advised on the implementation of the Plan. It sought to establish coordinated actions through guidelines and goals to restructure, reorganize, and expand the service to patients with these diseases in public services in a resolute manner with quality. These actions included screening and promotion of healthy habits, training and updating primary health care professionals, early diagnosis and linking of patients to health units for treatment and monitoring. As a result of this plan, the Hiperdia (Ordinance no. 371/GM) was created in 2002. This is a national computerized registration and monitoring system for patients with DM and $\mathrm{SAH}$ at the basic units of the Brazilian Health System (SUS, in the Portuguese acronym). Using the information created by the system it was possible to obtain better monitoring of patients, increased access to medication, and perspectives on strategic propositions in public health (also through permanent updating of the epidemiological profile). ${ }^{11,12}$

Currently, numerous prevention strategies are being carried out in an attempt to intervene early and effectively in the control of diabetes, hypertension, obesity, and associated risk factors in order to reduce the rates of these diseases and their complications. As such, this review sought to evaluate the main educational activities available in global literature about DM, SAH and OBES, aimed at future application in studies and actions focused on the prevention of these non-communicable chronic diseases in society.

\section{Method}

This study consisted of a literature review, without metaanalysis, on preventative strategies related to diabetes, hypertension and obesity. The methodologies used for the elaboration of this review were similar to those employed in systematic reviews. ${ }^{13-16}$

\section{Research strategy}

Our investigation was carried out using the Pubmed electronic database. The following combined descriptors were used: Prevention and Educational Activities and Hypertension; Prevention and Educational Activities and Obesity; Prevention and Educational Activities and Diabetes. The set of descriptors was followed by "not Systematic Reviews" at the end. Randomized studies published between 2002 and 2014 were included. The database was generated between the months of June and August 2015.

The articles selected were separated by subject: diabetes, hypertension, and obesity, with each theme distributed to two blinded independent reviewers. The inclusion of the studies was based on reading the titles and abstracts, noting whether they were "educational actions in healthcare for the prevention of chronic physiological diseases, mainly related to the DM, SAH, OBES triad." Publications with versions available in full through the CAPES portal or with free access were included. The articles were classified according to three main languages (Portuguese, English, and Spanish) for tabulation of the data. Next, the tasks were divided among the reviewers in order to gather the collected data in spreadsheets for quantitative analysis. Full photocopies of the selected articles were obtained for further discussion and qualitative assessment. The strategy described to prevent each pathophysiological condition (DM, HAS and OBES) 
was classified according to the population studied, age range, sex and preventive method adopted.

\section{RESULTS}

In accordance with the keywords used in the method, 8,908 articles were found on Pubmed, with 1,539 being selected as shown in Table 1. The greatest number of articles was related to DM and OBES. Most of the articles were related to OBES, demonstrating an exponential accumulation of publications in recent years.

Based on the classification of the articles by year of publication between 2002 and 2014, it was possible to observe that publications relating to the subject of health education for the prevention of DM and SAH remained stable during the period, with significant growth from 2012 onward. As for obesity, in 2008 there was a considerable increase in the number of publications and a boom starting in 2010.

\begin{tabular}{lllll}
$\begin{array}{l}\text { TABLE } 1 \text { Stratification of articles according to } \\
\text { investigated disease. }\end{array}$ & DM & SAH & OBES & Total \\
\hline Articles & 3,209 & 1,752 & 4,127 & 8,908 \\
\hline Identified & 2,629 & 1,173 & 2,781 & 6,583 \\
\hline Excluded based on title & 2,650 & 1,019 & 1,946 & 5,615 \\
\hline Excluded based on summary & 369 & 200 & 970 & 1,539 \\
\hline Selected & 93 & 82 & 289 & 464 \\
\hline Unavailable & 276 & 118 & 681 & 1,075 \\
\hline Available & & & & \\
\hline
\end{tabular}

DM: diabetes mellitus; SAH: systemic arterial hypertension; OBES: obesity.

In relation to the population studied in the articles (Table 2 ), the profiles investigated the most according to the publications reviewed were as follows: schoolchildren (mainly preschoolers and those in primary and secondary education), individuals that presented the disease (DM, SAH or OBES) or other comorbidities, ethnic groups, pregnant women, family members, and health or education professionals. There was also a significant amount of randomized articles. We also verified that in relation to diabetes and hypertension there was a predominance of articles focusing on patients with the disease or comorbidities and ethnic groups, while for obesity there was a predominance of student (preschool and those in primary/secondary education) and family populations.

In the classification of the articles according to the age range there was a significant number of randomized studies (Table 3). However, the most studied group was of adults, followed by children and young people, except in relation to OBES. The elderly population had low representation in all of the diseases covered. In relation to
TABLE 2 Study population according to the investigated disease in selected and available articles.

\begin{tabular}{lllll} 
Population & DM & SAH & OBES & Total \\
\hline Affected individuals & 95 & 36 & 61 & 192 \\
\hline School-aged children & & & & \\
\hline Preschoolers & 04 & 00 & 109 & 113 \\
\hline Primary/middle school & 19 & 12 & 183 & 214 \\
\hline University students & 03 & 00 & 12 & 15 \\
\hline Specific groups & & & & \\
\hline Ethnic & 48 & 08 & 37 & 93 \\
\hline Rural areas & 10 & 03 & 10 & 23 \\
\hline Relatives & 06 & 03 & 44 & 53 \\
\hline Presence of other comorbidities & 15 & 06 & 14 & 35 \\
\hline Hospitalized & 08 & 01 & 00 & 09 \\
\hline $\begin{array}{l}\text { Health professionals } \\
\text { Education professionals }\end{array}$ & 05 & 06 & 26 & 37 \\
\hline Pregnant women & 01 & 00 & 14 & 15 \\
\hline Other* & 09 & 01 & 18 & 28 \\
\hline Randomized & 12 & 10 & 36 & 58 \\
\hline Total & 41 & 32 & 117 & 190 \\
\hline * Other: predisposed or at risk of developing the disease, workers, nursing mothers, civil servants, \\
religious workers, fastfood consumers, the socioeconomically disadvantaged, caregivers, inter- \\
net users, homosexuals, athletes, sedentary individuals, and TV viewers. \\
DM: diabetes mellitus; SAH: systemic arterial hypertension; OBES: obesity.
\end{tabular}

the classification of articles regarding sex (Table 3 ), most were randomized (88.5\%), with more reports for women (10.4\%) than men $(1.1 \%)$.

When analyzing the articles selected in this research, we verified the use of various educational methodologies aimed at the prevention of the obesity, diabetes, and hypertension triad. The interventions were brief, medium, and long-lasting, taking place in hospitals, universities, schools, day care centers, rural areas, specific communities, and the internet, among other places. The main strategies employed in the educational activities for the prevention of chronic diseases were classified as: group dynamics and the practice of physical activity, nutritional education, educational talks and workshops, use of technologies, questionnaires, interviews, printed materials, training of people, clinical and laboratory monitoring, behavioral and lifestyle changes, among others (Table 3). We can highlight that the use of technologies through electronic media underwent a growing expansion in recent years, especially those related to publicizing campaigns or information, or primary health care and supervised treatment.

\section{Discussion}

After the industrial revolution, there was an adaptation of lifestyle to more harmful human habits, which were well-incorporated naturally by subsequent generations. Educa- 
TABLE 3 Classification according to age range, gender, and the education strategy used in the selected and available articles.

Classification

DM SAH OBES Total

Age range

\begin{tabular}{lllll}
\hline Children & 25 & 12 & 202 & 239 \\
\hline Youngsters & 23 & 08 & 180 & 211 \\
\hline Adults & 192 & 41 & 182 & 415 \\
\hline Elderly & 11 & 05 & 06 & 22 \\
\hline Randomized & 25 & 52 & 111 & 188 \\
\hline Total & 276 & 118 & 681 & 1,075 \\
\hline
\end{tabular}

\begin{tabular}{lllll}
\hline Gender & 07 & 02 & 03 & 12 \\
\hline Male & 19 & 07 & 86 & 112 \\
\hline Female & 250 & 109 & 592 & 951 \\
\hline Randomized & 276 & 118 & 681 & 1,075 \\
\hline Total & & & & \\
\hline Strategy & 71 & 28 & 193 & 292 \\
\hline Group dynamics and/or practice & & & & \\
of physical activity & 28 & 10 & 74 & 112 \\
\hline Nutritional education & 07 & 05 & 16 & 28 \\
\hline Printed materials & 33 & 18 & 60 & 111 \\
\hline Questionnaire & 35 & 14 & 52 & 101 \\
\hline Technologies & 36 & 23 & 51 & 110 \\
\hline Lectures and/or educational & & & & \\
\hline workshops & 14 & 04 & 30 & 48 \\
\hline Training of people & 20 & 06 & 44 & 70 \\
\hline Interviews & 47 & 14 & 197 & 258 \\
\hline Other* & $\mathbf{2 9 1}$ & $\mathbf{1 2 2}$ & $\mathbf{7 1 7}$ & $\mathbf{1 , 1 3 0}$ \\
\hline Total & & & & \\
\hline & & & & \\
\hline
\end{tabular}

* Other: monitoring of anthropometric measurements and laboratory results, nutritional and epide miological survey, implementation of public policies, correlation with sleep, lifestyle and behavior. DM: diabetes mellitus; SAH: systemic arterial hypertension; OBES: obesity.

tion has historically been the social institution that empowers the society. This sophisticated instrument can be used for health promotion. The three main non-communicable chronic diseases that plague the world today result, in general, from the influence of factors external to the individuals. These exogenous sources can be identifiable and controllable. Therefore, educational measures have a prophylactic function and depend on the social, political, economic, and cultural context, given that in most cases the risk conditions and behavior are shared as part of a collective profile. Public programs or policies focused on educational interventions for the prevention or control of diseases should be centralized nationally by the health system and aligned with global control perspectives, including universal actions permanently increasing regionalisms for healthy living. Low and middle income populations worldwide are the most affected by chronic diseases and their complications. ${ }^{17-19}$ However, although improvement to the economic condition or educational level of people is important to fight these contemporary diseases, a drastic reduction in their impact can only be achieved when the access to concrete health conditions is universalized. ${ }^{17,18,20-22}$ That is to say, the best methods or technologies will have little impact on modern and postmodern diseases if access is limited and especially coupled with economic power. Commodifying the problem means making social inequalities and the broad-spectrum of these diseases in a society worse. Prevention through extensive educational interventions positively supports the economy of the State by reducing massive spending on treatments and by keeping the workforce active, with a long lasting temporal effect. ${ }^{19,23}$ Intervention measures stabilize or decrease the incidence of chronic diseases, even when already present. ${ }^{19,24,25}$ Individuals need to identify with the process and feel a part of it. ${ }^{26,27}$ In this respect, the multidisciplinary pedagogical ways, the family participation, community health workers, social institutions, and public governance are very important in the control of the diabetes, hypertension, and obesity pandemy.

\section{Strategies in the school and social environment}

Universities, schools, and day care centers have been interesting targets for the dispersion of large scale interventionist practices aimed at the control of diseases, as well as being centers for intellectual and social training, functioning as centers that amplified the information and consequently repassed onto society. A Finnish study on the prevention of diabetes evaluated the effectiveness of lifestyle interventions according to level of education. Education levels were classified as: low (primary or secondary), medium (vocational cycle), and high (senior high school, college or academic degree). It was found that the effect of the intervention on the incidence of diabetes was independent of the level of education. ${ }^{28}$ A survey of schools in England with 644 children between the age of 7 and 11 focused on educational sessions aimed at the promotion of a healthy diet and discouraging the consumption of carbonated beverages. ${ }^{29}$ After a year of intervention during the school period, the anthropometric measurements, such as waist circumference and body mass index (BMI), were compared with the values obtained at the start of the study, demonstrating significant reductions in the number of overweight children. However, 2 years after the completion of the study, new measurements were made and it was observed that the number of overweight children had increased, showing the need, in some cases, to carry out interventions of longer duration. The conditions present in the family and school environment often contribute to chronic diseases. Inadequate sleep, sedentary lifestyle, consumption of soft drinks, and smoking are factors that can 
be associated with chronic diseases and some of these behaviors might lead to a poor school performance. ${ }^{30,31}$

A study conducted with African-American girls used an intervention involving after school dance classes and family education aimed at reducing the habit of watching television and videos, as well as practices linked to video games. The publication of informative newsletters and health education talks were also employed. ${ }^{32}$ The participants of the study showed a greater tendency toward loss of body mass, decreased waist circumference, adherence to physical activity after school, improvement of school grades, and a significant reduction of sedentary behavior, including watching television combined with a high calorie diet. Dramatization with playful messages related to health has been a promising and creative strategy for collective learning as a fun and educational event, providing an opportunity for leadership and group cooperation. A study of 108 children and 73 parents revealed that counseling children with such a strategy reflects positively on the parents' routine, especially in low income families. ${ }^{33}$ According to a stratified random sample of interviews with 1,500 parents of American children from kindergarten, it was found that individuals concerned with the weight of their children were significantly more likely to limit their sedentary hours, and to take steps to improve diet and increase physical activity. ${ }^{34}$

Anthropized Brazilian indigenous communities have often shown an increase in cases of diabetes, hypertension and obesity. A randomized and controlled study for the prevention of obesity in Native Americans schools in the US included 1,704 participants, aimed at changes in diet, increased physical activity, classes focused on nutrition, and healthy lifestyle habits in conjunction with a program of family involvement. ${ }^{35}$ The intervention included a combination of the social learning theory approach and practices of Native American culture. Thus, the traditions of the indigenous culture, such as the habit of telling stories, was incorporated into the multicomponent intervention, and proved to be viable in the implementation of the program for reduction of percentage body fat in American Indian schoolchildren.

Interventions in 75 adults with type 2 diabetes from a rural location in Costa Rica showed that participation in nutrition classes and walks improved the laboratory parameters such as glycated hemoglobin, glucose, total cholesterol, triglycerides, HDL, and LDL. ${ }^{36}$ The following anthropometric measurements were also compared: weight, height, and BMI, as well as blood pressure. Again, the indexes were better in the intervention group, with average weight loss of 1 to $2.2 \mathrm{~kg}$ compared to the control group.

Other points for building a social environment conducive to healthy living in the communities include: 1 ) strengthening primary health care bases, 2) higher per- formance of professionals trained in family health in outlying areas, 3) supporting religious institutions and community organizations for the establishment and dissemination of large-scale educational programs, 4) improving healthcare, sanitary, security, leisure and sports infrastructure (in particular, ensuring more access to parks, squares, swimming pools, sports courts, football pitches, and outdoor aerobic equipment). Mobile teams could be of interest in covering rural or remote areas, or even specific, socially vulnerable groups.

\section{Interventions in healthcare environments}

In 2005, a cross-sectional study conducted with 85 local health departments in North Carolina, USA, was performed to evaluate the prevention and control of diabetes. ${ }^{37}$ The questionnaires were sent via email to health center directors or professionals directly involved in the care of diabetics, who were subsequently used for interviews. It was noted that most services have limited capacity to conduct and coordinate preventive programs, including in local communities. Therefore, it is important for health professionals to be well trained to care for people in pre-dysfunction, carriers of chronic diseases or complicated cases. In addition, it is also relevant to maintain good communication and strong convincing about adherence to treatment. ${ }^{24}$ In another randomized study, interventions were carried out on employees at six hospitals in the United States through interviews and workshops to promote and prevent overweight and obesity, mainly through physical activity and healthy eating. ${ }^{38}$ Explanatory booklets were distributed containing practical and scientific advice for meal planning, including purchases, serving size, and storage of food, and information on training and exercises. Employees performed periodic community physical activities, such as hiking and yoga. Profession$\mathrm{al} /$ patient interaction dynamics, based on groups consisting of a maximum of 12 diabetics, have shown that the cognation for preventive actions can be acquired through pedagogical techniques aimed at sharing experiences and understanding individual experience. ${ }^{39}$ The main methodologies used for the systematization of the dynamics were a guidance course in diabetes mellitus, individual consultations, active groups, and the use of education material for communication and learning, such as: games to clarify doubts, the complications roulette, right $v s$. wrong, and diet traffic light.

\section{Physical activity: preventive and therapeutic alternative}

Numerous findings of the effectiveness of exercise in the prevention and control of obesity, hypertension, cardiovascular diseases, diabetes, and metabolic syndrome have been demonstrated. ${ }^{31,40-45}$ Unfortunately, the regular practice of physical exercise has been neglected by younger generations, 
with the sedentary lifestyle an increasingly frequent choice in contemporary life. ${ }^{41,45,46} \mathrm{~A}$ lot of children's time has been spent on video games, computers, TV, tablets, and mobile phones, which have been positively associated with psychic and physiological illness. ${ }^{31,47,48}$ Physical inactivity should be avoided, while the regular practice of sports, dancing, hiking, swimming, jogging, weight training, and yoga etc. should be more encouraged in society, including among people with chronic disorders. There is a general recommendation for the implementation of physical activity, which must be at 40 to $60 \%$ of the individual's maximum capacity, that is, moderate physical effort, which may be in a single session or a series of such. Individuals with a history of inactivity for long periods should start their physical activities with caution and under professional guidance.

Physical activity is conducive to better blood glucose control, significantly reducing the number of glycated proteins, as well as the reduction of weight and waist circumference, and is closely associated with the prevention of type 2 diabetes. In addition, it brings benefits to the circulatory system in relation to arterial structure, sympathetic activity, arterial elasticity, aortic wave reflection, and heart contraction speed. ${ }^{41}$

\section{Healthy eating: the first step to living longer and better}

The risk regarding the acquisition of chronic diseases such as obesity, diabetes and hypertension, especially in childhood, decreases considerably with a diversified and balanced diet rich in almonds, fruits, legumes, and vegetables, with an adequate intake of water, and avoiding the consumption of highly processed foods, carbonated beverages, and artificial juices. ${ }^{48-51}$ However, the high cost of healthier foods has made the access more difficult by economically disadvantaged populations. ${ }^{52}$ Meanwhile, the supply and demand for low-cost foods with lower nutritional value has increased, particularly in educational institutions for children and young people. ${ }^{53}$ Therefore, greater control and supervision of foods is essential in society in order to contain the advance of chronic diseases. The labeling of processed foods is an important way of educating consumers about the best nutritional choice. ${ }^{54}$

The regularity of meals has a positive impact on the homeostatic balance and the prevention of diseases. ${ }^{55}$ Poor food intake with fast food, chips, biscuits, pasta, and other foods of low nutritional quality, or infrequency in the first meal of the day were related to higher BMI, hyperglycemia, and dyslipidemia. ${ }^{55,56}$

Emotions are closely related to food. Negative mood disorders such as anxiety, depression, anger, loneliness, abandonment, and unemployment, among others, can lead to an increase in the consumption of foods with high caloric density. Individuals under greater emotional stress or solitary individuals show physiological problems more easily, ${ }^{27,31,57}$ especially in the presence of an inadequate diet.

\section{New technological approaches}

A dynamic virtual program for demonstrating health content built around "action research" and community-based interventions in Australia called SENTINEL has the objective of promoting skills to mitigate the high incidence of obesity, especially in children. ${ }^{58}$ The site includes intervention, training, evaluation, and monitoring actions in order to strengthen the capacities of communities regarding the promotion of a healthy diet, physical activity, and maintaining the appropriate weight in children. An internet-based diet program DASH has been used to verify behavioral changes associated with eating habits, in order to examine the effects on weight and blood pressure. Over 12 months, weekly articles about healthy nutrition were made available via the internet. The strategy reached 2,834 employees at the company EMC Corporation and their registered spouses, with their personal information and routines recorded, including the type of diet. Subsequently, it was observed that $735(26 \%)$ of the 2,834 subscribers were still actively using the program after a year. Individuals with hypertension or prehypertension $(\mathrm{n}=62)$ demonstrated a reduction in systolic blood pressure and diastolic blood pressure by an average of $6.8 \mathrm{mmHg}$ and $2.1 \mathrm{mmHg}$, respectively. In addition, the rate of obesity/overweight $(\mathrm{n}=151)$ declined significantly in the population. Based on self-recorded surveys about food, participants reported that they began a diet rich in fruits, vegetables, and grains, as well as reducing the consumption of carbonated drinks. ${ }^{59}$ In another investigation lasting 12 weeks, patients with diabetes sent daily messages via the internet or mobile phone with their glucose levels, and every week the nurses responded with ideal and individual recommendations for each patient through short, simple, and direction information. Constant messaging contributed to greater adherence to treatment, the practice of physical exercises and foot care. An average reduction of $1.1 \%$ in glycated hemoglobin levels was also noted. ${ }^{60}$ The production of mobile applications to selfconditioning and lifestyle changes are booming. Social marketing is another concept that has been employed for brief interventions with a wide reach in society. ${ }^{61}$

\section{Acting during pregnancy, affecting the offspring}

Pregnancy can be considered as a "teachable moment" in which prenatal care becomes more intense. ${ }^{62}$ Monitoring and counseling interventions aimed at encouraging healthy 
eating and physical exercise can significantly influence a reduction in the incidence of overweight and obesity in pregnant women and, consequently, in their offspring. Gestational weight gain and high retention of postpartum mass contribute to the future development of obesity in women. Approximately $25 \%$ of women retain weight greater than or equal to $4.5 \mathrm{~kg}$ associated with pregnancy. Overweight women are more prone to postpartum obesity. Excess weight gain during pregnancy has been linked to complications such as hypertension, diabetes mellitus, preeclampsia, cesarean birth, and macrosomia, as well as being associated with higher rates of obesity in the offspring. Obese pregnant women have a higher risk of miscarriage in early pregnancy, as well as recurrent abortions, congenital abnormalities such as neural tube, and heart problems in offspring. Other complications include chronic hypertension, pregnancyinduced hypertension, pregestational diabetes mellitus, gestational diabetes mellitus, urinary tract infection, asthma, obstructive sleep apnea, and gallbladder disease.

Since birth it is possible to investigate and take action to prevent chronic diseases in the childhood, juvenile, and adult stage. Breastfeeding, for example, reduces the risk of childhood obesity and, if lasting for more than 4 months, the risk of diabetes in adulthood. ${ }^{63,64}$ Raising awareness of parents, especially the mother, in the first years of life of children is another important factor to alleviate the excess weight in childhood. ${ }^{65}$ Detecting a high pulse in childhood has been considered as a predisposing factor to hypertension in adult life. ${ }^{66}$

\section{Psychological effects of prevention}

Educational interventions for a healthy diet, the practice of exercise and raising awareness have shown a positive impact on human development, especially in children, including changes in behavior, and intellectual and psychosocial gains. ${ }^{67}$ Teachers and family members have an important role in the relations of continued education and establishment of conscious perception.

A prevention program for type 2 diabetes, called the Tuebingen Lifestyle Intervention Program (TULIP), combined the use of methodologies related to the practice of regular physical exercises, changes in the nutrition of participants and analysis of somatic and psychosomatic variables. It revealed that after 9 months of lifestyle intervention on individuals without prior mental pathology, there was a significant reduction of mood disorders such as depression, anxiety, and distress. ${ }^{68}$

The relationship between people's instinctive perception and the real risk of contracting cardiovascular disease was assessed in a Dutch cross-sectional study conducted using a questionnaire during medical consultations involving 490 patients between 40 and 70 years of age. ${ }^{69}$ The recognition of the risk condition was most evident in smokers, hypertensive and obese patients than in diabetic patients. Women had greater perception. People with chronic illnesses with family members in similar condition showed greater adherence to healthy eating, changes in lifestyle and therapeutic methods. ${ }^{42}$

\section{Conclusion}

There is an urgent need to prevent the high incidence of chronic diseases such as DM, SAH, and OBES. Education and primary health care need to be at the forefront of the efforts to be undertaken at national, regional, and local level. Strategies targeted at children should be a priority, not only because they are more influenced by environmental factors, but also for being a group that will decide to follow healthy habits in the future. As such, it is of the utmost importance to elaborate and promote health education strategies specially in day care centers and schools. Children also act as good diffusers of the knowledge acquired to their family and community. In adulthood, many risk factors for $\mathrm{DM} / \mathrm{SAH} / \mathrm{OBES}$ can remain crystallized at the collective and individual-level and, in most cases, these diseases become irreversible. Therefore, interventionist methodologies should be based in accordance with the age group.

Another interesting point is that despite the majority of health education strategies aimed at DM/SAH/ OBES being focused on prevention, they can also influence the reversal of the symptoms already caused by such diseases, or even reduce the chances of complications. In this context, better training for health professionals is relevant not only to change their understanding of the concept of health/disease, but also to make them more prepared for multidisciplinary interventions.

The choice of educational methodology to be employed is critical for interventions, which need to generate immediate and long-term results. These cannot simply be limited to the habitual pamphlets and talks about dietary guidelines and the practice of physical activities. According to the review of the articles, we verified that campaigns addressing dynamics of psycho-socio-cultural interaction and creativity in the manner of capturing the public's attention had greater involvement and more lasting positive results. The definition, implementation, and results of methodological actions may vary according to cultural, ethnic, age, environmental, political, economic, and intellectual differences. In addition, with the incorporation of communication technologies in people's daily lives, their use as new resources for health education 
becomes inevitable, with a large number of articles demonstrating the positive use of electronic digital media.

Finally, studies covering long, prolonged or periodic monitoring, supervising the results with additional tips and guidelines, seem to have a greater impact on populations. Therefore, not only the mode of intervention but also its duration are important factors to consider in campaigns for the prevention of the major chronic diseases that are currently afflicting humanity.

\section{ACKNOWLEDGMents}

The Ministry of Education for granting scholarships to the Tutorial Education Program (PET-Medicina) from the Federal University of Mato Grosso.

\section{Resumo}

Estratégias educativas para prevenção de diabetes, hipertensão e obesidade

Objetivo: o objetivo central foi produzir uma revisão sobre as principais metodologias educativas para prevenção de diabetes, hipertensão e obesidade.

Método: a base de dados Pubmed foi consultada, sendo utilizados descritores combinados, como [Prevention], [Educational Activities], [Diabetes], [Hypertension] e [Obesity]. Dados de estudos randomizados publicados entre 2002 e 2014 foram incluídos em planilhas para análise em duplicata pelos revisores.

Resultados: um total de 8,908 artigos foi encontrado, sendo selecionados 1,539 sobre diabetes mellitus (DM, $\mathrm{n}=369)$, hipertensão arterial sistêmica (HAS, $n=200$ ) e obesidade (OBES, $n=970$ ). A quantidade de artigos completos gratuitos disponíveis foi de 1,075 (DM = 276, HAS = 118 e OBES =681). A maioria dos estudos que abordavam características demográficas, como sexo e idade, eram randomizados e compostos principalmente por escolares, familiares, grupos étnicos, gestantes, profissionais da saúde ou da educação, portadores da enfermidade ou de outras comorbidades. Dinâmicas de grupo, práticas de atividade física, educação nutricional, questionários, entrevistas, uso de tecnologias, capacitação de terceiros, palestras e oficinas educativas foram as principais estratégias de intervenção.

Conclusão: as intervenções mais eficazes ocorreram em nível comunitário, quando apresentavam caráter permanente ou alta periodicidade, ou porque contavam com a formação continuada dos agentes de saúde e sua interferência constante na população de abrangência. Muitos estudos focavam as ações em crianças e adolescentes, especialmente em escolares, constatando serem mais in- fluenciados pelas atividades educativas de prevenção e terem maior facilidade em difundir o aprendizado aos familiares e à sociedade.

Palavras-chave: diabetes, hipertensão, obesidade, prevenção, intervenção.

\section{References}

1. Lima-Costa MF, Veras R. Saúde pública e envelhecimento. Cad Saúde Pública. 2003; 19(3):700-1.

2. World Health Organization. Population ageing: a public health challenge Geneva: World Health Organization; 1998.

3. Veras RP, Parahyba MI. O anacronismo dos modelos assistenciais para idosos na área da saúde: desafios para o setor privado. Cad Saúde Pública. 2007; 23(10):2479-89.

4. World Health Organization. World Health Statistics 2012. Geneva: World Health Organization; 2012.

5. Associação Brasileira para o Estudo da Obesidade e da Síndrome Metabó lica. O Ministério da Saúde confirma: o número de obesos no país cresce a cada ano. Available from: http://www.abeso.org.br/noticia/o-ministerio-da-saude-confirma-o-numero-de-obesos-no-pais-cresce-a-cada-ano.

6. Ferreira VA, Wanderley EN. Obesidade: uma perspectiva plural. Ciênc Saúde Coletiva. 2010; 15(1):185-94.

7. Sociedade Brasileira de Cardiologia, Sociedade Brasileira de Hipertensão, Sociedade Brasileira de Nefrologia. VI Diretrizes Brasileiras de Hipertensão. Arq Bras Cardiol. 2010; 95(1 supl.1):1-51.

8. Agência Nacional de Saúde Suplementar. Manual técnico para promoção da saúde e prevenção de riscos e doenças na saúde suplementar. 4. ed. Rio de Janeiro: 2011.

9. Sociedade Brasileira de Diabetes. Diretrizes da Sociedade Brasileira de Diabetes. 3. ed. Itapevi: 2009.

10. King H, Aubert RE, Herman WH. Global burden of diabetes, 1995-2025. Diabetes Care. 1998; 21(9):1414-31.

11. Barbosa RB, Barceló A, Machado CA. Campanha nacional de detecção de casos suspeitos de diabetes mellitus no Brasil: relatório preliminar. Rev Panam Salud Publica. 2001; 10(5):324-7.

12. Toscano CM. As campanhas nacionais para detecção das doenças crônicas não-transmissíveis: diabetes e hipertensão arterial. Ciênc Saúde Colet. 2004; 9(4):885-95.

13. Cook DJ, Sackett DL, Spitzer WO. Methodologic guidelines for systematic reviews of randomized control trials in health care from the Potsdam Consultation on Meta-Analysis. J Clin Epidemiol. 1995; 48(1):167-71.

14. Pereira AL, Bachion MM. Atualidades em revisão sistemática de literatura, critérios de força e grau de recomendação de evidência. Rev Gaúcha Enferm. 2006; 27(4):491-8.

15. Manchikanti L, Benyamin RM, Helm S, Hirsch JA. Evidence-based medicine, systematic reviews, and guidelines in interventional pain management: part 3: systematic reviews and meta-analyses of randomized trials. Pain Physician. 2009; 12(1):35-72.

16. De-La-Torre-Ugarte-Guanilo MC, Takahashi RF, Bertolozzi MR. Revisão sistemática: noções gerais. Rev Esc Enferm USP. 2011; 45(5):1260-6.

17. Vialle-Valentin CE, Serumaga B, Wagner AK, Ross-Degnan D. Evidence on access to medicines for chronic diseases from household surveys in five lowand middle-income countries. Health Policy Plan. 2015; 30(8):1044-52.

18. Yusuf S, Rangarajan S, Teo K, Islam S, Li W, Liu L, et al. Cardiovascular risk and events in 17 low-, middle-, and high-income countries. N Engl J Med. 2014; 371(9):818-27.

19. Low WY, Lee YK, Samy AL. Non-communicable diseases in the Asia-Pacific region: prevalence, risk factors and community-based prevention. Int J Occup Med Environ Health. 2015; 28(1):20-6.

20. Cha SH, Park HS, Cho HJ. Socioeconomic disparities in prevalence, treatment, and control of hypertension in middle-aged Koreans. J Epidemiol. 2012; 22(5):425-32.

21. Rodin D, Stirbu I, Ekholm O, Dzurova D, Costa G, Mackenbach JP, et al Educational inequalities in blood pressure and cholesterol screening in nine European countries. J Epidemiol Community Health. 2012; 66(11):1050-5. 
22. Oza-Frank R, Hade EM, Norton A, Scarpitti H, Conrey EJ. Trends in body mass index among Ohio's third-grade children: 2004-2005 to 2009-2010. J Acad Nutr Diet. 2013; 113(3):440-6.

23. Trogdon JG, Larsen B, Larsen D, Salas W, Snell M. Cost-effectiveness evaluation of a collaborative patient education hypertension intervention in Utah. J Clin Hypertens (Greenwich). 2012; 14(11):760-6.

24. Martínez-Valverde S, Castro-Ríos A, Pérez-Cuevas R, Klunder-Klunder M, SalinasEscudero G, Reyes-Morales H. Effectiveness of a medical education intervention to treat hypertension in primary care. J Eval Clin Pract. 2012; 18(2):420-5.

25. Cortés DE, Millán-Ferro A, Schneider K, Vega RR, Caballero AE. Food purchasing selection among low-income, Spanish-speaking Latinos. Am J Prev Med. 2013; 44(3 Suppl 3):S267-73.

26. Levy MD, Loy L, Zatz LY. Policy approach to nutrition and physical activity education in health care professional training. Am J Clin Nutr. 2014; 99(5 Suppl):1194S-201S

27. Sundquist K, Hamano T, Li X, Kawakami N, Shiwaku K, Sundquist J. Linking social capital and mortality in the elderly: a Swedish national cohort study. Exp Gerontol. 2014; 55:29-36.

28. Wikström K, Peltonen M, Eriksson JG, Aunola S, Ilanne-Parikka P, KeinänenKiukaanniemi S, et al. Educational attainment and effectiveness of lifestyle intervention in the Finnish Diabetes Prevention Study. Diabetes Res Clin Pr. 2009; 86(1):e1-5.

29. James J, Thomas P, Kerr D. Preventing childhood obesity: two year followup results from the Christchurch obesity prevention programme in schools (CHOPPS). BMJ. 2007; 335(7623):762.

30. Park S, Sherry B, Foti K, Blanck HM. Self-reported academic grades and other correlates of sugar-sweetened soda intake among US adolescents. J Acad Nutr Diet. 2012;112(1):125-31.

31. Hoey H. Management of obesity in children differs from that of adults. Proc Nutr Soc. 2014; 73(4):519-25.

32. Robinson TN, Killen JD, Kraemer HC, Wilson DM, Matheson DM, Haskell WL, et al. Dance and reducing television viewing to prevent weight gain in African-American girls: the Stanford GEMS pilot study. Ethn Dis. 2003; 13(1 Suppl 1):S65-77.

33. Neumark-Sztainer D, Haines J, Robinson-O'Brien R, Hannan PJ, Robins M, Morris B, et al. 'Ready. Set. ACTION!' A theater-based obesity prevention program for children: a feasibility study. Health Educ Res. 2009; 24(3):407-20.

34. Moore LC, Harris CV, Bradlyn AS. Exploring the relationship between parental concern and the management of childhood obesity. Matern Child Health J. 2012; 16(4):902-8.

35. Caballero B, Clay T, Davis SM, Ethelbah B, Rock BH, Lohman T, et al.; Pathways Study Research Group. Pathways: a school-based, randomized controlled trial for the prevention of obesity in American Indian school children. Am J Clin Nutr. 2003; 78(5):1030-8.

36. Goldhaber-Fiebert JD, Goldhaber-Fiebert SN, Tristán ML, Nathan DM Randomized controlled community-based nutrition and exercise intervention improves glycemia and cardiovascular risk factors in type 2 diabetic patients in rural Costa Rica. Diabetes Care. 2003; 26(1):24-9.

37. Porterfield DS, Reaves J, Konrad TR, Weiner BJ, Garrett JM, Davis M, et al Assessing local health department performance in diabetes prevention and control - North Carolina, 2005. Prev Chronic Dis. 2009; 6(3):A87. Available from: http://www.cdc.gov/pcd/issues/2009/jul/08_0130.htm.

38. Zapka J, Lemon SC, Estabrook BB, Jolicoeur DG. Keeping a Step Ahead: formative phase of a workplace intervention trial to prevent obesity. Obesity (Silver Spring). 2007; 15(Suppl 1):27S-36S

39. Torres HC, Hortale VA, Schall V. [Experience with games in operative groups as part of health education for diabetics]. Cad Saúde Pública. 2003; 19(4):1039-47.

40. Drake KM, Beach ML, Longacre MR, Mackenzie T, Titus LJ, Rundle AG, et al. Influence of sports, physical education, and active commuting to school on adolescent weight status. Pediatrics. 2012; 130(2):e296-304.

41. Lackland DT, Voeks JH. Metabolic syndrome and hypertension: regular exercise as part of lifestyle management. Curr Hypertens Rep. 2014; 16(11):492

42. Tam CL, Bonn G, Yeoh SH, Wong CP. Investigating diet and physical activity in Malaysia: education and family history of diabetes relate to lower levels of physical activity. Front Psychol. 2014; 5:1328.

43. Milton K, Macniven R, Bauman A. Review of the epidemiological evidence for physical activity and health from low- and middle-income countries. Glob Public Health. 2014; 9(4):369-81.

44. Lavie CJ, Arena R, Swift DL, Johannsen NM, Sui X, Lee DC, et al. Exercise and the cardiovascular system: clinical science and cardiovascular outcomes. Circ Res. 2015; 117(2):207-19.

45. Kruk J. Health and economic costs of physical inactivity. Asian Pac J Cancer Prev. 2014; 15(18):7499-503.
46. Lifestyle prescriptions: a review of the clinical evidence [Internet]. Ottawa: Canadian Agency for Drugs and Technologies in Health; 2014. Available from: http://www.ncbi.nlm.nih.gov/books/NBK264048/

47. Gubbels JS, Kremers SP, Stafleu A, Goldbohm RA, de Vries NK, Thijs C. Clustering of energy balance-related behaviors in 5-year-old children: lifestyle patterns and their longitudinal association with weight status development in early childhood. Int J Behav Nutr Phys Act. 2012; 9:77.

48. Kovács E, Siani A, Konstabel K, Hadjigeorgiou C, de Bourdeaudhuij I, Eiben $\mathrm{G}$, et al. Adherence to the obesity-related lifestyle intervention targets in the IDEFICS study. Int J Obes. 2014; 38 Suppl 2:S144-51.

49. Foster GD, Shantz KL, Vander Veur SS, Oliver TL, Lent MR, Virus A, et al A randomized trial of the effects of an almond-enriched, hypocaloric diet in the treatment of obesity. Am J Clin Nutr. 2012; 96(2):249-54.

50. Spence AC, McNaughton SA, Lioret S, Hesketh KD, Crawford DA, Campbell KJ. A health promotion intervention can affect diet quality in early childhood. J Nutr. 2013; 143(10):1672-8.

51. Habib-Mourad C, Ghandour LA, Moore HJ, Nabhani-Zeidan M, Adetayo $\mathrm{K}$, Hwalla N, et al. Promoting healthy eating and physical activity among school children: findings from Health-E-PALS, the first pilot intervention from Lebanon. BMC Public Health. 2014; 14:940.

52. Slack T, Myers CA, Martin CK, Heymsfield SB. The geographic concentration of US adult obesity prevalence and associated social, economic, and environmental factors. Obesity (Silver Spring). 2014; 22(3):868-74.

53. Beets MW, Weaver RG, Tilley F, Turner-McGrievy G, Huberty J, Ward DS, et al. Salty or sweet? Nutritional quality, consumption, and cost of snacks served in afterschool programs. J Sch Health. 2015; 85(2):118-24.

54. Gordon C, Hayes R. Counting calories: resident perspectives on calorie labeling in New York City. J Nutr Educ Behav. 2012; 44(5):454-8.

55. Farshchi HR, Taylor MA, Macdonald IA. Beneficial metabolic effects of regular meal frequency on dietary thermogenesis, insulin sensitivity, and fasting lipid profiles in healthy obese women. Am J Clin Nutr. 2005;81(1):16-24.

56. Cahill LE, Chiuve SE, Mekary RA, Jensen MK, Flint AJ, Hu FB et al. A prospective study of breakfast eating and incident coronary heart disease in a cohort of male U.S. health professionals. Circulation. 2013;128(4):337-343.

57. Farrow CV, Haycraft E, Blissett JM. Teaching our children when to eat: how parental feeding practices inform the development of emotional eating-a longitudinal experimental design. Am J Clin Nutr. 2015; 101(5):908-13.

58. Bell AC, Simmons A, Sanigorski AM, Kremer PJ, Swinburn BA. Preventing childhood obesity: the sentinel site for obesity prevention in Victoria, Australia. Health Promot Int. 2008; 23(4):328-36.

59. Moore TJ, Alsabeeh N, Apovian CM, Murphy MC, Coffman GA, CullumDugan D, et al. Weight, blood pressure, and dietary benefits after 12 months of a Web-based Nutrition Education Program (DASH for health): longitudinal observational study. J Med Internet Res 2008; 10(4):e52.

60. Kim HS, Kim NC, Ahn SH. Impact of a nurse short message service intervention for patients with diabetes. J Nurs Care Qual. 2006; 21(3):266-71.

61. Gracia-Marco L, Moreno LA, Vicente-Rodríguez G. Impact of social marketing in the prevention of childhood obesity. Adv Nutr. 2012; 3(4):611S-5S.

62. Phelan S. Pregnancy: a "teachable moment" for weight control and obesity prevention. Am J Obstet Gynecol. 2010; 202(2):135.e1-8.

63. DiSantis KI, Hodges EA, Fisher JO. The association of breastfeeding duration with later maternal feeding styles in infancy and toddlerhood: a crosssectional analysis. Int J Behav Nutr Phys Act. 2013; 10:53.

64. Al Mamun A, O'Callaghan MJ, Williams GM, Najman JM, Callaway L, McIntyre HD. Breastfeeding is protective to diabetes risk in young adults: a longitudinal study. Acta Diabetol. 2015; 52(5):837-44.

65. Daniels LA, Mallan KM, Battistutta D, Nicholson JM, Perry R, Magarey A. Evaluation of an intervention to promote protective infant feeding practices to prevent childhood obesity: outcomes of the NOURISH RCT at 14 months of age and 6 months post the first of two intervention modules. Int J Obes. 2012; 36(10):1292-8.

66. Aatola H, Magnussen CG, Koivistoinen T, Hutri-Kähönen N, Juonala M, Viikari JS, et al. Simplified definitions of elevated pediatric blood pressure and high adult arterial stiffness. Pediatrics. 2013; 132(1):e70-6.

67. Sahota P, Rudolf MC, Dixey R, Hill AJ, Barth JH, Cade J. Randomised controlled trial of primary school based intervention to reduce risk factors for obesity. BMJ. 2001; 323(7320):1029-32.

68. Giel KE, Enck P, Zipfel S, Schrauth M, Bury A, Graf M, et al. Psychological effects of prevention: do participants of a type 2 diabetes prevention program experience increased mental distress? Diabetes Metab Res Rev. 2009; 25(1):83-8.

69. van der Weijden T, van Steenkiste B, Stoffers HE, Timmermans DR, Grol R. Primary prevention of cardiovascular diseases in general practice: mismatch between cardiovascular risk and patients' risk perceptions. Med Decis Making. 2007; 27(6):754-61. 


\section{ERRATUM}

http://dx.doi.org/10.1590/1806-9282.63.01.92

In the article "Educational strategies for the prevention of diabetes, hypertension, and obesity", DOI: http://dx.doi.org/10.1590/1806-9282.62.08.800 published in the journal Rev Assoc Med Bras, 62(8):800-808, on page 807 , where it reads:

"Metodologias educativas para prevenção de diabetes, hipertensão e obesidade: revisão sistemática" Change to:

"Estratégias educativas para prevenção de diabetes, hipertensão e obesidade" 